\title{
Arenas vs. Multifunctional Stadia - Which Do Spectators Prefer?
}

\author{
Arne Feddersen ${ }^{\dagger}$ and Wolfgang Maennig ${ }^{\dagger \dagger}$
}

August 2008

\begin{abstract}
Large sports stadia construction follows two different general concepts: (1) Mono-functional arenas which are specially suited for one sport exclusively and which are characterised by the absence of an athletic track. (2) Multifunctional sports stadia which can be used for different sporting or cultural events. Officials of clubs often argue that the atmosphere in an arena is significantly better than that of a multipurpose facility and that spectators prefer such an atmosphere. Estimated panel regressions with fixed effects show a significant positive effect of a mono-functional soccer stadium on spectator demand. Controlling for other demand determinants in the German professional soccer league, Bundesliga, an isolated effect of around 4,800 additional spectators a game can be found. This translates into a substantial increase of about $18.7 \%$ against the mean value of 25,602 spectators per Bundesliga game.
\end{abstract}

JEL Classification Codes: L83, C23, C24

Keywords: Demand for sport, soccer, mono-functional arenas, multifunctional stadia

This paper is also available as Hamburg Contemporary Economic Discussions, No. 14.

University of Hamburg, Department of Economics, Chair for Economic Policy, phone: 040 - 42838 - 4628, fax: 040 - 42838 - 6251, feddersen@econ.uni-hamburg.de

${ }^{\dagger}$ University of Hamburg, Chair for Economic Policy, Von-Melle-Park 5, 20146 Hamburg, Germany, E-mail: maennig@econ.uni-hamburg.de, phone: +49 (0)40 42838 - 4622 , fax: $+49(0) 4042838-6251$ 


\title{
Arenas vs. Multifunctional Stadia - Which Do Spectators Prefer?*
}

\begin{abstract}
Large sports stadia construction follows two different general concepts: (1) Mono-functional arenas which are specially suited for one sport exclusively and which are characterised by the absence of an athletic track. (2) Multifunctional sports stadia which can be used for different sporting or cultural events. Officials of clubs often argue that the atmosphere in an arena is significantly better than that of a multipurpose facility and that spectators prefer such an atmosphere. Estimated panel regressions with fixed effects show a significant positive effect of a mono-functional soccer stadium on spectator demand. Controlling for other demand determinants in the German professional soccer league, Bundesliga, an isolated effect of around 4,800 additional spectators a game can be found. This translates into a substantial increase of about $18.7 \%$ against the mean value of 25,602 spectators per Bundesliga game.
\end{abstract}

Keywords: Demand for sport, soccer, mono-functional arenas, multifunctional stadia JEL classification: L83, C23, C24

Version: September 2007

\section{Introduction}

Cities and clubs undertake significant efforts in stadia planning, finance and construction. Two different concepts can be identified: (1) Mono-functional arenas which are specially suited for soccer and which are characterised by the absence of an athletic track. (2) Multifunctional sports stadia which can be used for many different sporting or cultural events such as track and field championships, religious events etc. Soccer club officials often argue that the atmosphere in a pure soccer arena is significantly better than that of a multipurpose facility and that spectators prefer such an atmosphere. Thus, to obtain greater attendance, new stadia should be dedicated exclusively to soccer. Following this argumentation,

\footnotetext{
* We acknowledge Malte Borcherding, Florian Weinert and Philipp Zimmermann as well as the
} participants of the IMA Sport 2007 Conference. 
many of the old multifunctional stadia of the German professional soccer league, Bundesliga, have been rebuilt into pure soccer arenas, especially since the 1990s.

Empirical analysis of this line of argumentation is to date missing in the literature. This contribution considers the question of whether arenas attract more spectators by evaluating stadia construction in Germany in the period of the soccer seasons of $1963 / 64$ to $2005 / 06$. On the basis of the extensive literature on demand functions and novelty effects in team sports, panel analysis with clubspecific fixed effects is undertaken. The data include seasonal attendance per club for 43 seasons (13,100 matches) from the start of the Bundesliga in the 1963/64 season.

\section{Literature Review}

As BORLAND \& MCDONALD (2003, p. 480) pointed out, understanding the nature and determinants of demand is arguably one of the most important empirical issues in sports economic analysis. Team owners as well as managers, functionaries and public policy-makers cannot make correct judgements on issues of vital importance to them without having knowledge about demand. Since the initial research in the mid-1970s (DEMMERT, 1973; HART, HUTTON, \& SHAROT, 1975; NOLL, 1974), many demand studies have been undertaken on stadium attendance (BIRD, 1982; CZARNITZKI \& STADTMANN, 2002; DOBSON \& GODDARD, 1992; PEEL \& THOMAS, 1988; SIEGFRIED \& EISENBERG, 1980; SIMMONS, 1996). For an overview, see BORLAND \& MCDONALD (2003) or CAIRNS, JENNETT \& SLOANE (1986).

The novelty effect of stadia and arenas has hitherto been examined by means of various approaches. We find a number of difference-in-means approaches in the form of before-and-after comparisons of spectator figures, for example in the work of QUIRK \& FORT (1992), HAMILTON \& KAHN (1997) and HOWARD \& CROMPTON (2003). Econometric procedures have been also employed, whereby differentiation is made between two fundamental approaches. In the first approach, assumptions with regard to the time duration and characteristics of the 
novelty effect are given exogenously with the aid of dummy variables (COATES \& HUMPHREYS, 1999, 2005; KAHANE \& SHMANSKE, 1997; POITRAS \& HADLEY, 2003). NOLL (1974) and COFFIN (1996) constructed a variable that decreases as the age of the stadium increases and which adopts a zero value at a point in time defined by the author. BRUGGINK \& EATON (1996) used the age of the stadium as an explanatory variable.

Empirical analysis of the effect of mono-functional arenas which are specially suited for one sport exclusively on attendance is to date missing in the literature.

\section{Data and Model}

The econometric analysis is based on fixed effects panel analysis using averaged game-by-game data on a seasonal basis. Therefore, the variable "average number of spectators for clubs in the Bundesliga per season" was created using the seasonal arithmetic mean of the 13,100 games played in the Bundesliga in the period of the soccer seasons of $1963 / 64$ to $2005 / 06$ as published by the (DFB, 2006). The highest average number of spectators in the history of the Bundesliga was recorded by Borussia Dortmund in the 2003/04 season, with 79,647 per home game. This followed the third period of reconstruction since the mid-1990s, which saw the total capacity of the Westfalia Stadium increase to 83,000. The absolute lowest average number of spectators was recorded by RW Oberhausen in the 1972/73 season with 6,941 spectators per home game. The highest average number of spectators taken across all seasons observed here was attained by Borussia Dortmund with 39,587 spectators in 661 home games (39 seasons) followed by Bayern Munich with 38,976 spectators in 699 home games (41 seasons). The mean value for the entire sample is 25,602 spectators per game.

To test the effect of a pure soccer arena, we set up a broad demand model of stadium attendance, considering the afore-mentioned literature. We performed panel analysis with fixed effects to measure unobserved club-specific effects. The 
estimation equation used is based on FEDDERSEN, MAENNIG \& BORCHERDING (2006):

$$
\begin{aligned}
& A T_{i t}=\alpha_{i}+\beta_{1}{I N C O M E_{i t}}+\beta_{2} P O S_{i t}+\beta_{3} W O_{i t}+\beta_{4} \Delta C A P+\beta_{5} M A R K E T_{i t}+\beta_{6} B S_{i t} \\
& +\beta_{7} N E_{i t}+\beta_{8} A_{R E N A_{i t}}+\varepsilon_{i t}
\end{aligned}
$$

where ATT is the average number of spectators for clubs in the Bundesliga per season. INCOME is average gross monthly earnings of salaried staff in trade and industry. The data is available for the entire period from 1964 to 2003, taken from STATISTISCHES BUNDESAMT (various years). These nominal values were deflated using the CPI (consumer price index), taken from INTERNATIONAL MONETARY FUND (2006). Whilst older studies dealing with previous periods usually come to the conclusion stadium visits are inferior goods, so that increasing income leads to falling demand, more recent studies have come to the conclusion they are normal goods.

Latest studies on the demand behaviour of soccer stadium visitors tend to reject the hypothesis that the uncertainty of outcome is the central determining factor. By contrast, the emphasis is now on the sporting success of the home team (PEEL \& THOMAS, 1992). Consequently, our calculations below also take home team wins into account. The first variable that depicts sporting success is POS which indicates the final position in the league table that the individual teams achieved in the season in question. A better league table position at the end of the season is assumed to lead to a higher number of spectators. There is, however, no need for a control variable for current or lagged sporting success of the guest teams when considering seasonal average spectator figures, since over the course of the season every team plays home games against every other team in the league.

Weekend games (normally held at around 3.30 p.m. on Saturdays or 5.30 p.m. on Sundays) may have a higher number of spectators than weekday games, usually held at around 8.00 p.m. on Tuesdays, Wednesdays and Fridays. This applies in particular to visiting spectators who have to travel a long way to get to the match. The effects that arise due to Bundesliga matches played during the week are depicted by the variable $W Q$, which is the ratio of the number of home games 
of club $i$ during the week and the total number of home games of club $i$ in season j multiplied by 100 .

In order to take into consideration the fact that the "market" of a Bundesliga team also extends beyond the boundaries of the team's home town, or that it may be limited by the geographical proximity of a league competitor, the market size is also depicted by the distance between the clubs. This takes into account the fact that a greater average distance to the other clubs means a larger regional market in which a club can act as a monopolist. There is an increase both in the number of potential spectators and also in the number of individuals that have no (close) fan relationship to the local club, but who, for lack of alternative entertainment, nevertheless consume the commodity of a "stadium visit or event" during home team games. In this case, the number of spectators would increase as the average distance to the next competitor increases. However, an opposite effect is also conceivable, since fans of the away team must also be seen as potential consumers of stadium visits. In such a case the "derby effect" resulting from the lowest average distance between the teams would lead to a greater number of spectators. A variable corresponding to the average linear distance to the nearest rival team's stadium assumes a geographically homogenous distribution of soccer fans. In reality, however, one should assume that such a constant distribution does not exist. Rather, we may presume that the readiness of soccer fans to travel to a league game is only given within a certain distance to the stadium. For this reason the following regressions make use of the distance-based variable MARKET which is the number of Bundesliga rivals for each team in a given season that can be found within a 100 kilometer radius from the team's home town.

A number of studies concerned with the novelty effect of new or reconstructed stadia use a variable that takes the capacity of individual stadia into account (COFFIN, 1996; NOLL, 1974; POITRAS \& HADLEY, 2003). The inclusion of stadium capacity as an explanatory variable is however problematic, both as a result of a possible multicollinearity of the capacity with other variables and as a result of an inadequate distinction between capacity and novelty effects. In the case of clubs that regularly have maximum capacity crowds in their stadia prior to the addition 
of supplementary capacity, it is unclear whether the increased demand following the opening of new or reconstructed stadia is due to the new or reconstructed stadia themselves or whether it merely means that existing excess demand had not been met. By contrast, for clubs that had a regularly underused stadium capacity prior to construction or reconstruction, hardly any capacity effects on spectator demand are expected. A variable that is designed to discriminate between capacity and novelty effects must, therefore, only take into account a change in capacity in the context of a stadium construction project when capacity restriction was previously binding. To this end we have constructed the variable $\triangle C A P$, which assumes the value of the percentage capacity change for clubs that displayed an average capacity utilisation of over $90 \%$ in the three seasons prior to the opening of new or reconstructed stadia.

$$
\Delta C A P=\left\{\begin{array}{cc}
\frac{C A P_{t}}{C A P_{t-1}} \cdot 100 & \text { for } \sum_{i=t-3}^{t-1} \frac{\text { capacity utilisation }}{3}>0.9 \\
0 & \text { for } \sum_{i=t-3}^{t-1} \frac{\text { capacity utilisation }}{3} \leq 0.9
\end{array}\right.
$$

It is to be expected that the average number of spectators increases when $\triangle C A P$ is positive, given that in such a case it may be assumed that a capacity effect occurs in addition to the novelty effect.

The dummy variable $N E$ is intended to isolate the novelty effect of a newly or reconstructed stadium. Its design is oriented towards theoretical reasoning on the novelty effect as discussed in FEDDERSEN, MAENNIG \& BORCHERDING (2006, p. 175). This dummy variable assumes that the novelty value remains constant over the following five seasons, and assumes the value of zero for subsequent seasons.

Finally a further dummy variable is also taken into account which is intended to isolate the effects of the Bundesliga bribery scandal of the 1970/71 season. Since the accusations only came to light following the 1970/71 season, the dummy variable $B S$ assumes the value of one for the 1971/72 season and the value of zero otherwise. 
Some other variables were tested but excluded: CONSTR is a dummy variable that isolates negative effects which may occur during the construction phase. In addition to problems of capacity and possible inconvenience during construction, it is also conceivable that the prospect of a new stadium may lead potential spectators to temporarily postpone proposed consumption to the post-opening period. $D F B$ and ECC are measures for additional sporting success in the German Cup and in European Cup competitions the season before.

\section{Results}

Firstly, a number of panel unit root tests were carried out to examine the stationarity characteristics of the panel. Recent research suggests that panel-based unit root tests are more powerful in a pooled dataset than unit root tests based on individual time series (OUANTITATIVE MICRO SOFTWARE, 2007, p. 100). In the following, several panel unit root tests are employed. Thereby, a common unit root process (HADRI, 2000; LEVIN, LIN, \& CHU, 2002) as well as an individual unit root process (CHOI, 2001; IM, PESARAN, \& SHIN, 2003; MADDALA \& WU, 1999) are assumed.

Tab. 1 Panel Unit Root Tests

\begin{tabular}{|c|c|c|c|c|c|}
\hline Test & ATT & INCOME & POS & WO & MARKET \\
\hline $\begin{array}{l}\text { Lin, Levin and Chu } \\
\text { test }\end{array}$ & $\begin{array}{l}-1.653^{* *} \\
(0.049)\end{array}$ & $\begin{array}{c}-16.2588^{\cdots} \\
(0.000)\end{array}$ & $\begin{array}{l}-2.798^{* * *} \\
(0.003)\end{array}$ & $\begin{array}{l}-7.287^{* * *} \\
(0.000)\end{array}$ & $\begin{array}{l}-3.721^{* * *} \\
(0.000)\end{array}$ \\
\hline Hadri test & $\begin{array}{l}15.330^{* * *} \\
(0.000)\end{array}$ & $\begin{array}{c}28.167^{* * *} \\
(0.000)\end{array}$ & $\begin{array}{l}7.6022^{* * *} \\
(0.000)\end{array}$ & $\begin{array}{l}2.944^{* * * *} \\
(0.002)\end{array}$ & $\begin{array}{c}4.812^{\cdots} \\
(0.000)\end{array}$ \\
\hline $\begin{array}{l}\text { Im, Pesaran and } \\
\text { Shin test }\end{array}$ & $\begin{array}{l}-1.637^{*} \\
(0.051)\end{array}$ & $\begin{array}{l}-5.778^{\cdots} \\
(0.000)\end{array}$ & $\begin{array}{l}-6.387^{* *} \\
(0.000)\end{array}$ & $\begin{array}{l}-9.764^{* *} \\
(0.000)\end{array}$ & $\begin{array}{l}-3.585 \\
(0.000)\end{array}$ \\
\hline $\begin{array}{l}\text { Fisher-type test } \\
\text { (ADF) }\end{array}$ & $\begin{array}{l}82.493^{* * *} \\
(0.003)\end{array}$ & $\begin{array}{c}184.054 \\
(0.000)\end{array}$ & $\begin{array}{c}162.8599^{\cdots} \\
(0.000)\end{array}$ & $\begin{array}{c}240.847^{\cdots *} \\
(0.000)\end{array}$ & $\begin{array}{l}83.7422^{\cdots *} \\
(0.000)\end{array}$ \\
\hline $\begin{array}{l}\text { Fisher-type test } \\
\text { (PP) }\end{array}$ & $\begin{array}{c}111.608 \\
(0.000)\end{array}$ & $\begin{array}{c}281.329 \cdots \\
(0.000)\end{array}$ & $\begin{array}{c}186.730 \\
(0.000)\end{array}$ & $\begin{array}{c}265.087^{\cdots} \\
(0.000)\end{array}$ & $\begin{array}{l}87.478 \cdots \\
(0.000)\end{array}$ \\
\hline
\end{tabular}

Notes: $p$-values are in parentheses; ${ }^{* * *} p<0.01 ;{ }^{* *} p<0.05 ;{ }^{*} p<0.10$; Probabilities for Fisher tests are computed using an asymptotic $\chi^{2}$ distribution. All other tests assume asymptotic normality (BALTAGI, 2001, pp. 235-243). 
On the basis of these panel root tests, no problems of non-stationarity of the data were evident. Only the Im, Pesaran and Shin (IPS) test for attendance is significant only at the $10 \%$ level. The other variables used in equation (1) are not tested since they have the character of dummy variables.

Equation (1) is estimated by two different econometric methods. First, a linear ordinary least square (OLS) regression is applied. Second, empirical analysis of the demand function in professional team sports faces the problem of excess demand or capacity constraints. If this phenomenon is ignored, the OLS estimators may be biased. For this purpose we also estimated our model as a censored regression (Tobit) model. Both models were performed as fixed effects models. ${ }^{1}$ The results of the regressions are summarized in Table 1 . The fixed effects play no role in the subsequent interpretation of the results. However, the values of the $\mathbf{4 9}$ fixed effects are given in Table 2 for the sake of completeness.

For further details on fixed effects models using panel data, see BALTAGI (2001, pp. 212-214). 
Tab. 2 Panel Regression

\begin{tabular}{|c|c|c|}
\hline Variable & OLS & Tobit \\
\hline INCOME & $\begin{array}{c}6.620 \\
(11.554)\end{array}$ & $\begin{array}{c}6.6788^{\cdots} \\
(12.069)\end{array}$ \\
\hline POS & $\begin{array}{c}-426.203 \\
(-7.618)\end{array}$ & $\begin{array}{c}-425.017 \\
(-7.824)\end{array}$ \\
\hline WO & $\begin{array}{c}-172.456 \\
(-5.045)\end{array}$ & $\begin{array}{c}-178.072 \\
(-5.376)\end{array}$ \\
\hline$\triangle \mathrm{CAP}$ & $\begin{array}{r}225.839 \\
(3.077)\end{array}$ & $\begin{array}{c}228.253 \\
(3.232)\end{array}$ \\
\hline MARKET & $\begin{array}{c}-1,527.042 \\
(-5.241)\end{array}$ & $\begin{array}{c}-1,537.041 \\
(-5.383)\end{array}$ \\
\hline BS & $\begin{array}{c}-2,840.398 \\
(-2.368)\end{array}$ & $\begin{array}{c}-2,835.394 \\
(-2.451)\end{array}$ \\
\hline NE & $\begin{array}{c}2,529.422 \\
(3.654)\end{array}$ & $\begin{array}{c}2,508.615 \\
(3.741)\end{array}$ \\
\hline ARENA & $\begin{array}{r}4,801.346 \\
(4.039)\end{array}$ & $\begin{array}{c}4,854.159 \\
(4.242)\end{array}$ \\
\hline $\mathrm{N}$ & 772 & 772 \\
\hline Mean & 25,602 & 25,602 \\
\hline$R^{2}$ & 0.658 & - \\
\hline $\operatorname{adj} . R^{2}$ & 0.631 & - \\
\hline F-statistic / Log L & $24.589^{* * *}$ & $-7,783.155$ \\
\hline
\end{tabular}

Notes: ${ }^{* * *} p<0.01 ;{ }^{* *} p<0.05 ;{ }^{*} p<0.10$; Heteroskedasticity consistent t-statistics are given in parentheses; 7 observations are right-censored in the Tobit model.

The results of the OLS and Tobit estimations are quite similar. It seems that the results of the OLS regression are not biased by the capacity constraints. This result is not surprising because only 7 out of 772 observations are right-censored. ${ }^{2}$ For this reason, in the following, only the results of the OLS regression are discussed unless otherwise noted.

The coefficients in Table 1 show the expected signs. In more detail, the variable $\triangle C A P$ is significantly positive at the $5 \%$ level. It should be borne in mind here that the reason for inclusion of this variable is not for independent interpretation of this variable, but rather is designed to assist in differentiating between capacity and novelty effects arising from a new stadium.

2 GREENE (2004, p. 137) pointed out that if none of the observations were censored, this would be a linear regression model, and the resulting OLS estimator would be the consistent linear LSDV estimator. 
From the significant and negative leading signs of the regression coefficients of the variable MARKET, we may conclude that the average number of spectators per game falls by 1,527 spectators with every Bundesliga club located within a 100 $\mathrm{km}$ radius from the home team.

The Bundesliga bribery scandal of the 1970/71 season shows a negative effect on average attendance. The average attendance in the season after the scandal was 2,840 spectators lower. This confirms the findings by FRICK (1999) and FEDDERSEN (2008).

The regression coefficient of the variable $N E$ is positively significant. A newly built or renovated stadium leads to a novelty effect of around 2,530 spectators per game. This corresponds to a substantial increase of $9.88 \%$ against the mean value of 25,602 spectators per Bundesliga game. With regard to the variable ARENA, which is of decisive importance for the question formulated in this study, a significant positive effect of a pure soccer arena can be found. The isolated effect amounts to 4,801 additional spectators per game in comparison to a multifunctional stadium. This corresponds to a substantial increase of about $18.7 \%$ against the mean value of 25,602 spectators per Bundesliga game. Thus, it can be shown that a bigger distance between the spectators and the spectators in combination with a lack of atmosphere due to an athletic track is an essential factor for spectator demand. This regression displays an $R^{2}$ of 0.658 and an adjusted $R^{2}$ of 0.631 .

The results of the regressions in Table 2 also indicate that spectators prefer weekend games. From a club's point of view this means that an additional match day during the week, corresponding to an increase of $W Q$ of 5.88 percentage points, leads to a decrease of around 1,014 spectators per game. Implementation of a Monday evening match (an increase in WQ of 11.76 percentage points) leads to a decrease of about 2,029 spectators per game. 
Tab. 3 Fixed Effects

\begin{tabular}{|c|c|c|}
\hline Club & OLS & Tobit \\
\hline Bayern München & 26,015 & 25,931 \\
\hline Hamburger SV & $17,378^{\cdots}$ & $17,281 \cdots$ \\
\hline Werder Bremen & $12,822^{* * *}$ & $12,738^{* *}$ \\
\hline VfB Stuttgart & $18,892 \cdots$ & 18,806 \\
\hline 1. FC Köln & $23,793^{\cdots}$ & $23,773 \cdots$ \\
\hline 1.FC Kaiserslautern & $13,089 \cdots$ & 12,972 \\
\hline Borussia Mönchengladbach & $15,394^{* * *}$ & $15,309^{\cdots *}$ \\
\hline Borussia Dortmund & $29,815^{* * *}$ & $29,814^{* *}$ \\
\hline Eintracht Frankfurt & $15,446 \cdots$ & $15,368 \cdots$ \\
\hline FC Schalke 04 & $29,836 \cdots$ & $29,756 \cdots$ \\
\hline Bayer 04 Leverkusen & $8,045^{\cdots}$ & $8,329 \cdots$ \\
\hline VfL Bochum & $16,969^{\cdots}$ & $16,900 \cdots$ \\
\hline MSV Duisburg & $19,802^{* \cdots}$ & $19,782 \cdots$ \\
\hline Hertha BSC Berlin & $25,215^{\cdots}$ & $25,148 \cdots$ \\
\hline 1. FC Nürnberg & $19,730 \cdots$ & $19,640 \cdots$ \\
\hline Fortuna Düsseldorf & $20,486^{\cdots}$ & $20,475 \cdots$ \\
\hline TSV 1860 München & $18,768^{\cdots \cdots}$ & $18,658 \cdots$ \\
\hline Karlsruher SC & $18,441^{\cdots}$ & $18,375 \cdots$ \\
\hline Eintracht Braunschweig & $13,309^{\prime \prime}$ & $13,256 \cdots$ \\
\hline Hannover 96 & $19,943^{\cdots}$ & $19,873 \cdots$ \\
\hline KFC Uerdingen & $6,616^{\cdots}$ & 6,556 \\
\hline Arminia Bielefeld & $6,418 \cdots$ & $6,737^{\cdots}$ \\
\hline Hansa Rostock & $9,229 \cdots$ & $9,121 \cdots$ \\
\hline SC Freiburg & 3,513 & 3,970 \\
\hline VfL Wolfsburg & 1,957 & 1,810 \\
\hline SVW Mannheim & $7,028 \cdots$ & $6,935 \cdots$ \\
\hline Kickers Offenbach & $8,659^{\cdots}$ & $8,566 \cdots$ \\
\hline RW Essen & 19,491 & 19,427 \\
\hline FC St. Pauli & 7,323 & 8,638 \\
\hline Wattenscheid 09 & $13,764 \cdots$ & $13,742 \cdots$ \\
\hline Dynamo Dresden & $11,693 \ldots$ & $11,603 \ldots$ \\
\hline 1.FC Saarbrücken & $19,210 \cdots$ & $19,161 \cdots$ \\
\hline RW Oberhausen & $21,058 \cdots$ & $21,075 \cdots$ \\
\hline Alemania Aachen & $11,931 \cdots$ & $11,842 \cdots$ \\
\hline Energie Cottbus & 3,154 & 2,978 \\
\hline Wuppertaler SV & $19,692^{* \cdots}$ & 19,686 \\
\hline Borussia Neunkirchen & $10,948 \cdots$ & 10,825 \\
\hline FC Homburg & $4,446^{* * *}$ & $4,390^{\cdots}$ \\
\hline 1. FSV Mainz & 1,498 & 1,301 \\
\hline SpVgg Unterhaching & 1,466 & 1,368 \\
\hline Stuttgarter Kickers & 2,206 & 2,075 \\
\hline SV Darmstadt & 12,173 & 12,084 \\
\hline TB Berlin & 10,164 & 10,069 \\
\hline SSV UIm & 13,195 & 13,080 \\
\hline Fortuna Köln & 20,132 & 20,135 \\
\hline Preußen Münster & 26,011 & 26,017 \\
\hline Blau-Weiß Berlin & $18,231^{\cdots}$ & $18,263^{\cdots}$ \\
\hline VfB Leipzig & $6,976^{\cdots \cdots}$ & $6,844 \cdots$ \\
\hline Tasmania Berlin & $12,995 \cdots$ & $12,882 \ldots$ \\
\hline
\end{tabular}

Notes: ${ }^{* *} p<0.01 ;{ }^{* *} p<0.05 ;{ }^{*} p<0.10$. 
Since the fixed effects are unobservable individual specific effects, if one assumes a well specified equation (1), they can be interpreted as club-specific effects or "autonomous consumption". This autonomous consumption is highest for Borussia Dortmund and FC Schalke 04, which is consistent with the intuition since these two clubs have on of the biggest fan bases in their home market in the German Bundesliga. For the most part, the fixed effects are significant at the $1 \%$ level. Only in five cases are the fixed effects not significant In addition, for Energie Cottbus and SC Freiburg, there were significant fixed effects only at the $10 \%$ level in the Tobit model.

\section{Conclusions}

Following the argumentation that the atmosphere in an arena is significantly better than that of a multipurpose facility and that spectators prefer such an atmosphere, many of the old European multifunctional stadia have been rebuilt into arenas during the last decade or so. An empirical test of this hypothesis had so far-especially for the German Bundesliga-been missing. The aim of this study was to measure the effect of a mono-functional arena specially suited for soccer on soccer spectator figures in Germany. To this end, all stadium construction projects since the start of the Bundesliga in the 1963/64 season) were processed and data from all 13,100 completed games up to the end of the 2005/06 season were used. Multivariate panel regression, which, in addition to the dummy variable depicting "pure soccer stadium", tested for further influences on spectator behaviour, displayed a significant increase in the average number of spectators of around 4,800 spectators per season in such a mono-functional arena. This translates into a substantial increase of about $18.7 \%$ against the mean value of 25,602 spectators per Bundesliga game. This effect is almost twice as high as that of the novelty effect estimated by FEDDERSEN, MAENNIG \& BORCHERDING (2006). In contrast to the novelty effect, which only lasts for a few years, the effect of a "pure soccer arena" is enduring. 
The income from additional spectators may provide a significant contribution to the finances of stadia. Using a "back of the envelope"-type calculation, the arena effect of 4,801 spectator leads to around 81,600 additional spectators per season, given 17 home games per season. Assuming an average ticket revenue of $€ 16.81$ (DFL, 2006), which translates into an additional annual income of around $€ 1.4$ million. This corresponds to $1.2 \%$ of the average volume of investment per "World Cup 2006" stadium of $€ 116,750,000$ (FIFA, 2004), indicating that a significant share of capital costs of stadia could be financed via the "arena effect".

\section{Literature}

BALTAGI, B. H. (2001). Econometric analysis of panel data (2. ed.). New York: John Wiley.

BIRD, P. J. W. N. (1982). The Demand for League Football. Applied Economics, 14(6), 637-649.

BORLAND, J., \& MCDONALD, R. (2003). Demand for Sport. Oxford Review of Economic Policy, 19(4), 478-502.

BRUGGINK, T. H., \& EATON, J. W. (1996). Rebuilding Attendance in Major League Baseball: The Demand for Individual Games. In J. L. FIZEL, E. F. GUSTAFSON \& L. H. HADLEY (Eds.), Baseball Economics: Current Research. Westport, Conn.: Praeger.

CAIRNS, J. A., JENNETT, N., \& SLOANE, P. J. (1986). The Economics of Professional Team Sports: A Survey of Theory and Evidence. Journal of Economic Studies, 13(1), 1-80.

CHOI, I. (2001). Unit Root Tests for Panel Data. Journal of International Money and Finance, 20(2), 249-272.

COATES, D., \& HUMPHREYS, B. R. (1999). The Growth Effects of Sport Franchises, Stadia, and Arenas. Journal of Policy Analysis and Management, 18(4), 601-624.

COATES, D., \& HUMPHREYS, B. R. (2005). Novelty Effects of New Facilities on Attendance at Professional Sporting Events. Contemporary Economic Policy, 23(3), 436-455.

COFFIN, D. A. (1996). If You Build It, Will They Come? Attendance and New Stadium Construction. In J. L. FIZEL, E. F. GUSTAFSON \& L. H. HADLEY (Eds.), Baseball Economics: Current Research. Westport, Conn.: Praeger.

CZARNITZKI, D., \& STADTMANN, G. (2002). Uncertainty of Outcome versus Reputation: Empirical Evidence for the First German Football Division. Empirical Economics, 27(1), 101-112. 
DEMMERT, H. G. (1973). The Economics of Professional Team Sports. Lexington/Mass. and London.

DFB. (2006). Bundesliga. http://www.dfb.de/bliga/bundes/ index.html, from august 25th, 2006.

DFL. (2006). Bundesliga Report 2006. Frankfurt a.M.: DFL.

DOBSON, S. M., \& GODDARD, J. A. (1992). The Demand for Standing and Seated Viewing Accommodation in the English Football League. Applied Economics, 24(10), 1155-1163.

FEDDERSEN, A. (2008). Steuerungsmöglichkeiten der Wettbewerbsintensität: Eine ökonomische Analyse sportpolitischer Regulierungen. Berlin: Duncker \& Humblot.

FEDDERSEN, A., MAENNIG, W., \& BORCHERDING, M. (2006). The Novelty Effect of New Soccer Stadia: The Case of Germany. International Journal of Sport Finance, 1(3), 174-188.

FIFA. (2004). Auf nach Deutschland. Stadien. <http://fifaworldcup.yahoo.com/ 06/de/d/stadium/index.html>, 12th May 2004.

FRICK, B. (1999). Kollektivgutproblematik und externe Effekte im professionalisierten Team-Sport: Spannungsgrad und Zuschauerentwicklung im bezahlten Fußball. In H. D. HORCH, J. HEYDEL \& A. SIERAU (Eds.), Professionalisierung im Sportmanagement (pp. 144-160). Aachen: Meyer \& Meyer.

GREENE, W. (2004). Fixed Effects and Bias Due to the Incidental Parameters Problem in the Tobit Model. Econometric Reviews, 23(2), 125 - 147.

HADRI, K. (2000). Testing for Stationarity in Heterogeneous Panel Data. Econometrics Journal, 3(2), 148-161.

HAMILTON, B. W., \& KAHN, P. (1997). Baltimore's Camden Yards Ballparks. In R. G. NOLL \& A. ZIMBALIST (Eds.), Sports, jobs, and taxes: The economic impact of sports teams and stadiums (pp. 245-281). Washington, D.C.: Brookings Institution Press.

HART, R. A., HUTTON, J., \& SHAROT, T. (1975). A Statistical Analysis of Association Football Attendances. Applied Statistics, 24(1), 17-27.

HOWARD, D. R., \& CROMPTON, J. L. (2003). An Empirical Review of the Stadium Novelty Effect. Sport Marketing Quarterly, 12(2), 111-116.

IM, K. S., PESARAN, M. H., \& SHIN, Y. (2003). Testing for Unit Roots in Heterogeneous Panels. Journal of Econometrics, 115(1), 53-74.

IMF. (2006). International Financial Statistics [Electronic Version]. Retrieved 16 November 2006 from http://www.imfstatistics.org.

KAHANE, L., \& SHMANSKE, S. (1997). Team Roster Turnover and Attendance in Major League Baseball. Applied Economics, 29(4), 425-431.

LEVIN, A., LIN, C.-F., \& CHU, C.-S. J. (2002). Unit Root Tests in Panel Data: Asymptotic and Finite-Sample Properties. Journal of Econometrics, 108(1), 1-24. 
MADDALA, G. S., \& WU, S. (1999). A Comparative Study of Unit Root Tests with Panel Data and a New Simple Test. Oxford Bulletin of Economics and Statistics, 61, 631-652.

NOLL, R. G. (1974). Attendance and Price Setting. In R. G. NOLL (Ed.), Government and the Sports Business. Washington, DC: Brookings Institution.

PEEL, D. A., \& THOMAS, D. A. (1988). Outcome Uncertainty and the Demand for Football: An Analysis of Match Attendances in the English Football League. Scottish Journal of Political Economy, 35(3), 242-249.

PEEL, D. A., \& THOMAS, D. A. (1992). The Demand for Football: Some Evidence on Outcome Uncertainty. Empirical Economics, 17(2), 323-331.

POITRAS, M., \& HADLEY, L. (2003). Do New Major League Ballparks Pay For Themselves? Working Paper Series WP03-6E, School of Business Administration, University of Dayton, Dayton.

OUANTITATIVE MICRO SOFTWARE. (2007). EViews 6 Users's Guide (Vol. II). Irvine, CA: Quantitative Micro Software LLC.

QUIRK, J. P., \& FORT, R. D. (1992). Pay Dirt: The Business of Professional Team Sports. Princeton, NJ: Princeton Univ. Press.

SIEGFRIED, J. J., \& EISENBERG, J. D. (1980). The Demand for Minor League Baseball. Atlantic Economic Journal, 8(2), 59-69.

SIMMONS, R. (1996). The Demand for English League Football: A Club-Level Analysis. Applied Economics, 28(2), 139-155.

STATISTISCHES BUNDESAMT. (various years). Statistisches Jahrbuch für die Bundesrepublik Deutschland. Wiesbaden: Statistisches Bundesamt. 


\section{Hamburg Contemporary Economic Discussions}

(Download: http://www.uni-hamburg.de/economicpolicy/discussions.html)

01/2005 FEDDERSEN, A. / MAENNIG, W.: Trends in Competitive Balance: Is there Evidence for Growing Imbalance in Professional Sport Leagues?, January 2005.

02/2005 SIEVERS, T.: Information-driven Clustering - An Alternative to the Knowledge Spillover Story, February 2005.

03/2005 SIEVERS, T.: A Vector-based Approach to Modeling Knowledge in Economics, February 2005.

04/2005 BUETTNER, N. / MAENNIG, W. / MENSSEN, M.: Zur Ableitung einfacher Multiplikatoren für die Planung von Infrastrukturkosten anhand der Aufwendungen für Sportstätten - eine Untersuchung anhand der Fußball-WM 2006, May 2005.

01/2006 FEDDERSEN, A.: Economic Consequences of the UEFA Champions League for National Championships - The Case of Germany, May 2006.

02/2006 FEDDERSEN, A.: Measuring Between-season Competitive Balance with Markov Chains, July 2006.

03/2006 FEDDERSEN, A. / VOEPEL, H.: Staatliche Hilfen für Profifußballclubs in finanziellen Notlagen? - Die Kommunen im Konflikt zwischen Imageeffekten und Moral-Hazard-Problemen, September 2006.

04/2006 MAENNIG, W. / SCHWARTHOFF, F.: Stadium Architecture and Regional Economic Development: International Experience and the Plans of Durban, October 2006. 


\section{Hamburg Contemporary Economic Discussions}

(Download: http://www.uni-hamburg.de/economicpolicy/discussions.html)

01

02

03

04

05

06

07

08

O9

10

11

12

13

AHLFELDT, G. / MAENNIG, W.: The Role of Architecture on Urban Revitalization: The Case of "Olympic Arenas" in Berlin-Prenzlauer Berg, 2007.

FEDDERSEN, A. / MAENNIG, W. / ZIMMERMANN, P.: How to Win the Olympic Games - The Empirics of Key Success Factors of Olympic Bids, 2007.

AHLFELDT, G. / MAENNIG, W.: The Impact of Sports Arenas on Locational Attractivity: Evidence from Berlin, 2007.

DU PLESSIS, S. / MAENNIG, W.: World Cup 2010: South African Economic Perspectives and Policy Challenges Informed by the Experience of Germany 2006, 2007.

HEYNE, M. / MAENNIG, W. / SUESSMUTH, B.: Mega-sporting Events as Experience Goods, 2007.

DUST, L. / MAENNIG, W.: Shrinking and Growing Metropolitan Areas - Asymmetric Real Estate Price Reactions? The Case of German Single-family Houses, 2007.

JASMAND, S. / MAENNIG, W.: Regional Income and Employment Effects of the 1972 Munich Olympic Summer Games, 2007.

HAGN, F. / MAENNIG W.: Labour Market Effects of the 2006 Soccer World Cup in Germany, 2007.

HAGN, F. / MAENNIG, W.: Employment Effects of the World Cup 1974 in Germany.

MAENNIG, W.: One Year Later: A Re-appraisal of the Economics of the 2006 Soccer World Cup, 2007.

AHLFELDT, G., MAENNIG, W.: Assessing External Effects of City Airports: Land Values in Berlin, 2007.

AHLFELDT, G.: If Alonso was Right: Accessibility as Determinant for Attractiveness of Urban Location, 2007.

AHLFELDT, G.: A New Central Station for a Unified City: Predicting Impact on Property Prices for Urban Railway Network Extension, 2007. 


\section{Hamburg Contemporary Economic Discussions}

(Download: http://www.uni-hamburg.de/economicpolicy/discussions.html)

Which Do Spectators Prefer?, 2007. 
